\title{
Economic evaluation of the losses caused by exception of lands and limitations in land-use
}

\author{
I. Novakovska, \\ Candidate of Sciences (Economics) \\ National Aviation University
}

The purpose. To study trends in cutting the areas of productive lands and order of refunding the caused losses of agriculture and forestry, and also ways of perfecting their legislative and normative regulation. Methods. Analysis, generalization, simulation. Results. Productivity of implementation of the system of refunding losses and ways of its development is analyzed, as well as directions of perfecting economic gear of losses evaluation and their refunding. Conclusions. The existing regulating system of relations connected to exception of lands, requires revision of doses, application of indexes of money evaluation of lands, change of approaches to determination of losses in cities, legislative solution of compensation to proprietors and users of land of the losses caused by limitations in land-use and deterioration of quality of lands.

Key words: land-use, losses of agricultural and forestry production, agricultural lands, urban lands.

Redistribution of land between sectors of the national economy, landowners and land users and economic activity, which causes anthropogenic impact o land resources, cause loss of agricultural land and forest lands. From agricultural and forestry management significant areas are deduced, damages and losses are caused due to deterioration of soil cover properties, as well as land-use constraints. The cost of previously incurred costs (buildings, structures, plantations, unfinished construction, etc.) is lost. Losses concern only land owners and land users, and losses of agricultural and forestry production, caused by the exclusion from circulation of the relevant lands, reduce or limit the land-resource potential of the entire state [2]. Only in the last 2 years, for example, more than 2.2 thousand hectares of agricultural land have been seized for non-agricultural needs.

The Civil Code of Ukraine (Article 22) characterizes losses as losses incurred by a person in connection with the destruction or damage to the thing, as well as the expenses that a person has or should do to restore his violated right (actual losses and incomes) which person could actually be obtained under normal circumstances, if its right was not violated (lost profit) [10].

The list of losses caused by seizure (redemption) and temporary occupation of land plots, the establishment of restrictions on their use, the deterioration of land quality or their incapacity and lack of income due to temporary non-use of land plots to be compensated by landowners is legally determined and land users. The amount of damage caused by the unauthorized occupation of land, the use of land not for specific purposes, the removal of soil (fertile soil layer) without special permission is calculated according to a special method approved by the Government of Ukraine in July 2007. Procedure for calculating the amount of compensation for damage caused as a result of pollution land with chemicals, their clogging with waste, established by a special methodology. The Cabinet of Ministers of Ukraine in December 2008 adopted a resolution on determining the amount of damages caused by non-implementation of works on the reclamation of disturbed lands.

Due to the lack of effective legal and organizational measures for the protection of agricultural land and forest areas from sequestration, measures of economic regulation were introduced in the form of compensation for losses of agricultural and forestry production. For the first time, the necessity of compensation for losses of agricultural production was introduced in 1962, in 1964 - 1974, the order of compensation was improved, and in 1975 for each of the regions the norms for the development of new lands instead of agricultural lands withdrawn for non-agricultural needs were approved. In 1983, these standards were revised and increased 2.5 times, taking into account the points of economic land valuation that was completed. The need for compensation for losses in forestry production was introduced by the 
Land Code of Ukraine, adopted on December 18, 1990, and the procedure for compensation for these losses was approved in October 1991 [7].

Due to its legal nature, the loss of agricultural and forestry production is significantly different. Agricultural lands of the majority are privatized, owned by legal entities and individuals, and in case of their redemption for non-agricultural needs, land owners should receive appropriate compensation for alienated land. The state with the withdrawal (redemption) of land for non-agricultural needs loses part of its base for food production. Instead of alienated areas, it is necessary to master the equivalent areas of new lands or to improve the productivity of existing lands by intensifying production, which would make it possible to replace the quantities of products that are not received as a result of the alienation. This requires appropriate capital investment.

Since forest lands and shrubs are dominated by the constant use of forestry enterprises and are state owned, the state loses its forestry resource when the land is seized, and the said enterprises carry out work on the restoration of the forested areas with funds transferred to them from the budgets received in the form of compensation losses of forestry production [6].

Concerning the losses related to the restriction of the rights of land owners and land users, or with the deterioration of the quality of land, direct land owners and land users should have direct relation to their compensation. However, the Land Code (Art. 209) regulated only the issue of compensation for losses caused by the removal of agricultural land, forest lands and shrubs (these funds are credited to the relevant budgets in the manner prescribed by the Budget Code of Ukraine).

The list of objects exempted from compensation for losses of agricultural and forestry production is quite wide and not always justified. Citizens and legal entities are exempted from the compensation for the indicated losses in case of use of land plots for the construction of schools, preschool institutions, public facilities for health care, culture, physical education and sports, social security, state road construction objects, religious organizations of religious organizations , cemeteries, reclamation systems, anti-erosion, anti-slip and anti-slip structures, for the construction and maintenance of dwelling houses and household buildings, for the placement of farm Agricultural, fisheries and forestry enterprises, organizations and institutions for placement of the infrastructure of wholesale markets for agricultural products, peat extraction, subject to the return of land in a condition suitable for pre-utilization, for objects and territories of the nature reserve fund, for construction and servicing of energy facilities that produce electricity from alternative sources of energy, for afforestation of degraded and low-rise land on the basis of with land organization, as well as all-Ukrainian public organizations of invalids of Ukraine, their enterprises (associations), institutions and organizations financed from the State Budget of Ukraine in case of use of land for the construction of rehabilitation institutions for disabled persons and children with disabilities, physical education objects, sport and social security for the disabled and children with disabilities [3, art. 208].

The main principle by which citizens and legal entities should be exempted from compensation is the belonging of the types of needs and works - exemptions to activities directly related to the development of new lands, the improvement of existing lands or socially significant construction. In connection with the above, it is quite controversial to exempt from compensation for losses in the use of sites for the construction of state-owned road facilities, religious structures of religious organizations, for the placement of infrastructure of wholesale markets for agricultural products, and objects of alternative energy sources.

A number of problems are associated with the untimely utilization of funds received for the reimbursement of losses to the budgets of local councils and are kept for a long time on their deposit accounts. The list of works for which you can use these funds often changes and unreasonably expands. The use of these funds for land inventory, normative monetary valuation of land plots is not directly related to restoring food and forestry potential. Some local governments insist on the inclusion in the current legislation of the possibility of using these funds and on the preparation of master plans of rural settlements, other urban planning documents [1].

Losses in agricultural and forestry production include:

(a) Loss of agricultural land, forest lands and shrubs as the main means of production in agriculture and forestry, which are conditional on their removal (redemption) for needs not related to agricultural and forestry production. Agricultural lands include arable land, perennial plantations, perlini, hayfields, pastures;

b) losses caused by restrictions of rights of land owners and land users; 
including tenants, in connection with the exclusion of agricultural land, forest lands and shrubs from economic circulation due to the establishment of protective, sanitary and other protective zones;

e) losses caused by deterioration of the quality of the land due to the negative impact caused by the activities of citizens, legal entities, local governments or the state.

The said losses are compensated irrespective of the indemnification to the owners of land and land users.

The size of losses of agricultural and forestry production, which are subject to reimbursement, are established according to the norms approved by the Cabinet of Ministers of Ukraine in November 1997 [8].

The norms are determined for each of the regions (Autonomous Republic of Crimea, the oblast, the city of Kyiv and Sevastopol) by types of land (arable land, perennial stands, hayfields, pastures), as well as forest groups (first and second groups). In terms of losses, the highest values of norms are: for arable land Chernivtsi region. (139.94 thousand UAH per 1 hectare), for perennial plantations - Zhytomyrska (652,90 thousand UAH for 1 hectare), for the hayfields - Volynska (92.28 thousand UAH for 1 hectare), for the Volyn region (74, 02 thousand UAH for 1 hectare). The lowest rates are for arable land - Luhansk region. (65.89 thousand UAH for 1 hectare), for perennial plantations - Kirovogradskaya (95.37 thousand UAH for 1 hectare), for haymowers - Kherson (13.71 thousand UAH for 1 hectare), for pastures - Kherson ( 12.62 thousand UAH for 1 hectare).

Comparison of norms by regions indicates that they do not correlate with indicators of normative monetary valuation of land in the region. If, for example, in Transcarpathian region the standard of losses for arable land is higher than its monetary value in 6.17 times, then in Cherkassy - only 3.71, and in Zaporozhye - 2.65 times. Levels of norms of other lands also vary considerably by region in comparison with the normative monetary estimation and are not equal to each other. This is especially evident on the example of the capital of Ukraine - Kyiv (Table 1).

Attention is drawn to the particularly low level of production losses in the removal of arable land compared with their assessment. If we take into account that the normative monetary value of 1 hectare of arable land in greenhouses reaches 372,8 thousand $U A H$, then for 116,74 thousand UAH this area will not be able to recover.

Within the city, the level of land valuation is significantly underestimated, as evidenced by changes in the purpose of agricultural land. When rendering arable land for different types of construction, the cost of plots increases by $50-85$ times. Consequently, both the rates of agricultural production losses and the indicators of monetary valuation of agricultural land in cities should be substantially increased.

The determination of losses of agricultural and forestry production, which are subject to reimbursement, is carried out in the following order.

The losses of agricultural production caused by the removal of agricultural land (arable land, perennial plantations, hayfields, pastures) for use for non-agricultural purposes are determined on the basis of the norms of these losses in the Autonomous Republic of Crimea, oblasts, cities of Kyiv and Sevastopol by the formula:

$P_{B}=P_{D} \cdot H_{B} \cdot D_{B} / B_{O} \cdot K_{I N T}$

where $P_{B}$ - the size of losses of agricultural production, thousand $U A H ; P_{D}$ - area of agricultural land, hectares; $H_{B}$ - standard of losses of agricultural production, thousand $U A H ; D_{B}$ - the bonus point of the area of agricultural land withdrawn; $B_{\circ}$ - a bonus point of agricultural land in the Autonomous Republic of Crimea, the oblast, cities of Kyiv and Sevastopol; $\mathrm{K}_{\mathrm{INT}}$ is the coefficient of intensity of use of agricultural lands (the ratio of the indicator of differential income of the evaluation of arable land of the land valuation district in which the land plot is allocated, to a similar indicator in the whole of the Autonomous Republic of Crimea, the oblast, the cities of Kyiv and Sevastopol).

Losses in forestry production, caused by the removal of forest lands (covering the forest vegetation of lands, unbreakable forest crops, forest nurseries, plantations, forest trees, fires, dead plantations, log cabins, lawns, forest paths, trenches, fire bridges, etc.), for their use for purposes not per ' with the management of forestry, are determined on the basis of the norms of losses in the Autonomous Republic of Crimea, oblasts, cities of Kyiv and Sevastopol by the formula:

$$
P_{B}=P_{D} \cdot H_{B} \cdot K_{1}
$$


where $P_{B}$ - the size of losses of forestry production, thousand UAH; $P_{D}$ - the area of the area of the forestry area withdrawn, ha; $H_{B}$ - norm of losses of forestry production, thousand UAH; $K_{I}$ - productivity factor of forest lands by types of forest vegetation (Table 2).

Losses of agricultural and forestry production caused by restrictions on the rights of land owners and land users, including tenants, or deterioration in the quality of land caused by the impact of the activities of enterprises, institutions and organizations, are determined by the following formula:

$P_{B}=(1-K) \cdot H_{B} \cdot P_{D}$

where $P_{B}$ - the size of losses, thousand UAH; K - coefficient of reduction of productivity of the land; $H_{B}$ average loss per hectare; $P_{D}$ - area of the site, ha.

Due to the widespread application of economic calculations of production losses, their norms should be clarified on the basis of the monetary valuation of land, and in the formulas, instead of the points of the bonitee, use of monetary valuation indicators. It should be borne in mind that bonitty points are comparable only to the level of the natural and agricultural area. Their application at the level of the Autonomous Republic of Crimea and the oblast is incorrect.

Serious problems are related to the groundlessness of the reduction factor because of the specific criteria for establishing its size depending on the types of restrictions on the rights of regimens and, depending on the nature of the deterioration of land quality, has not yet been proposed. In this direction, research is ongoing, proposals for the settlement of some issues have been developed, and the results of a comprehensive solution to the problem have not yet been achieved [5, 9].

Although the law provides for the reimbursement of losses associated with land use restrictions and the deterioration of land quality, in practice this provision is not applicable. Legislation has not yet approved a specific calculation of these losses and the procedure for their reimbursement. Agricultural enterprises, citizens and legal entities - land owners, because of the declarative norms of the current laws, annually deprived of the possibility of receiving compensatory payments due to reduced productivity of land.

\section{Conclusions}

Losses in agricultural and forestry production, related to restrictions on the rights of owners and users of land and degradation of land quality, should be compensated irrespective of compensation for losses to landowners and land users. However, the procedure for their recovery by law is not established. The list of objects exempted from compensation for losses is not directly related to the development of new lands and increase the productivity of available land. Norms of losses do not correlate with indicators of normative monetary valuation of lands, unreasonably understated, and the cost of losses is determined by the use of bonitet points by region (ARC, oblast), which is incorrect. The estimation of agricultural land and the size of the norms of production losses within cities are extremely low, and the size of the coefficients of land productivity decline is still uncertain. Improvement of economic regulation of losses determination and their compensation requires application instead of points of bonitetes, indicators of normative monetary valuation of lands, revision of the methodology of this assessment within cities, scientific determination of the dimension of the coefficients of decline in land productivity, legislative regulation of the compensation for losses caused by restrictions on land use and deterioration of the quality state lands.

\section{Bibliography}

1. Hutsulyak H. D. Metodolohichni ta metodychni zasady optymizatsiyi pryrodokorystuvannya i zemlekorystuvannya/H.D. Hutsulyak, Yu.H. Hutsulyak//Zbalansovane pryrodokorystuvannya. - 2016. — № 2. - S. $82-87$.

2. Dovidnyk iz zemleustroyu; za red. L.Ya. Novakovs'koho. - 4-te vyd., pererob. i dop. - K.: Ahrar. nauka, 2015. - $492 \mathrm{~s}$.

3. Zemel'nyy kodeks Ukrayiny vid 25 zhovtnya 2001 r. № 2768 - III //Vidomosti Verkhovnoyi Rady Ukrayiny. - 2002. - № 3-4. - S. 27.

4. Dobryak D.S. Klasyfikatsiya sil's'kohospodars'kykh zemel' yak naukova peredumova yikh ekolohobezpechnoho vykorystannya/D.S. Dobryak, O.P. Kanash, D.I. Babmindra, I.A. Rozumnyy. - K.: Urozhay, 2009. - $464 \mathrm{~s}$. 
5. Nedashkivs'ka T.M. Formuvannya ta otsinka obmezhen' i obtyazhen' u sil's'kohospodars'komu zemlekorystuvanni: [nauk. monohr.]/T.M. Nedashkivs'ka, D.S. Dobryak. — K., 2014. — 164 s.

6. Novakovs'ka I.O. Osnovy ekonomiky zemlekorystuvannya: [monohr.]/l.O. Novakovs'ka. - K.: Prosvita, 2013. - $224 \mathrm{~s}$.

7. Novakovs'ka I.O. Transformatsiya sil's'kohospodars'koho zemlekorystuvannya: [monohr.]/ I.O. Novakovs'ka. - Chernivtsi: Prut, 2010. - 208 s.

8. Pro rozmiry ta poryadok vyznachennya vtrat sil's'kohospodars'koho i lisohospodars'koho vyrobnytstva, yaki pidlyahayut' vidshkoduvannyu: postanova Kabinetu Ministriv Ukrayiny № 1279 vid 17 lystopada 1997 r.//Ofits. visn. Ukrayiny. — 1997. — № 47. — S. 40.

9. Tretyak A.M. Ekolohiya zemlekorystuvannya: teoretyko-metodolohichni osnovy formuvannya ta administruvannya: [monohr.]/A.M. Tretyak. — Kherson: Hrin' D.S.,

2012. $-440 \mathrm{~s}$.

10. Tsyvil'nyy kodeks Ukrayiny vid 16 sichnya 2003 r. № 435 - IV//Vidomosti Verkhovnoyi Rady Ukrayiny. - 2003. - № $40-44$. - S. 356. 